\title{
The Matter of the Sovereignty of the Heathen Peoples
}

\author{
Maria Stella Ferreira Levy \\ Epidemiology Department, School of Public Health of The University of Sao Paulo (USP) \\ Brasil
}

\section{Introduction}

The objective of this study is to provide as evidence certain facts and legal provisions in which, since the conquest of the American peoples, the kings of Portugal and Spain, the Catholic Church and the colonists of these matrices in the New World were the main players, in the sense that they all subjugated the natives of the Americas, in our case Brazil.

We begin our considerations with the controversy surrounding to whom the "discovered" territories belonged and how the inhabitants and their lands were to be treated. This is followed by the ambiguous and contradictory positions of the Church, the king's letters, the regulations and authorizations of the metropolis and the laws of Brazil and its governments since the time of the "conquest" up to the Federal Constitution of 1988.

Lastly, we turn to the rebirth of the indigenous peoples that survived and that still try to exist and survive through an endless struggle.

\section{Discovery or invasion?}

The question of the sovereignty of heathen peoples following the Iberian territorial conquests in North Africa and South Asia is to be found in the ecclesiastical milieu since long before the "discovery" (finding, as some would have it) and conquest of America, and was fundamental in the argument about the legitimacy of Spanish and Portuguese title to the New World.

With the arrival of the Spaniards on the Islands, the controversy about their inhabitants begins, namely that if they were not Hindus but rather Aruaks, they should be treated as infidels or heathens since if they were unfamiliar with the "good word" they should be persuaded and there would be no place for the "just war" 1 , unless they remained deaf to the word of God. A huge theological, moral, intellectual and legal debate takes place in the conquering/colonizing nations, above all on the Iberian Peninsula, especially given the symbiotic relationship between those royal households and the Catholic Church. There were

1 The " just war" was defined in Mércio Pereira GOMES, Os Índios e o Brasil, Rio de Janeiro, Vozes, 1988, page 69:" declaration of war based on a joint decision made which ruled on the correctness of the war it was intended to wage against a given indigenous people". 
two opposing theses regarding the attitude of the conquerors towards the Native Americans:

On the one hand, the archbishop of Ostia, the XIII century canonist and author of Summa Aurea, based on the assumption that the heathen peoples had only enjoyed sovereignty until Christ came down to Earth. The latter was invested with all spiritual and temporal powers, and through his delegation it was now incumbent on the pope who could take and distribute their domains, which afforded legitimacy to the Treaty of Tordesillas and several others that followed it.

On the other hand, "the canonist pope Innocent IV, also in the XIII century, had argued that the papacy could not strip the faithful of their domains and jurisdictions ... [and] Thomas Aquinas argued against the Ostian that the coming of Christ had not annulled the chattels and sovereignty of the heathen peoples".

It is in this environment that what the authors ${ }^{3}$ refer to as the "Valladolid Debate" arises, with repercussions way beyond the debate that took place between the canonist of Córdoba - Ginés de Sepulveda, the official historiographer of Charles I of Spain and V of Germany and mentor of his successor the future Philip II of Spain; and on the other side, the Dominican monk Bartolomé de Las Casas "Indian Defender", who incited Charles V to enact in 1542 the Nuevas Leyes which ordered the extinction of the encomiendas and "laid down the basic rules of life and administrative organization of America, dealing with the condition of the natives, the Council of the Indians, the awards and recompenses for those who discovered new lands, etc." 4

The encomienda was a piece of land and its inhabitants, in this case natives, handed over to the "encomendero" (grantee) who was entitled to exploit the land and the natives. Under the law it was non transferrable and limited to a short time span that grew as the years passed. "The "encomienda" went from an initial servitude, the so-called "encomienda de servicios" to a "encomienda de tributos" using the economic system of the principal American peoples based on taxes by caste or people, also called the Asian production mode". This legislation of domination, applied to the regions where the natives themselves were organized under this tax system, subjugates the natives, exchanges the chiefs for "encomenderos" and uses their organization to structure the colonies. ${ }^{5}$

\footnotetext{
2 According to Cunha, Maria Manuela Ligeti Carneiro da, Os Direitos do índio Ensaios e documentos, São Paulo, Brasiliense, 1987, pages 53 to 58.

${ }^{3}$ Term used by ROULAND, Norbert, PIERRE-CAPS, Stephane \& POUMARÈDE, Jaques. Droits des minorités et des peoples autochtones. Paris, Presses Universitaires de France, 1996. pg 113

${ }^{4}$ Carlos Frederico Marés de SOUZA FILHO, in the chapters: "As leis de Índias" and "Las casas, jurisdição e territorialidade indígena" in his book O renascer dos povos indígenas para o Direito, Curitiba, Juruá, 1999. For those interested in the opinions of Las Casas himself, it is worth taking a look at the chapter Princípios para defender a justiça dos Indios, taken from the work of Las Casas and published in : Carlos Frederico Marés de Souza Filhos (org.), Textos clássicos sobre o direito e os povos indígenas, 93-124, Curitiba, Juruá/NDI, 1992. The controversy between the authors mentioned is dealt with by Enrique DUSSEL, from the very particular point of view of the "origin of the myth of modernity", in his book 1492: O encobrimento do outro, Petrópolis, Vozes, 1993, pages 75 to 88.

${ }^{5}$ Carlos Frederico marés de SOUZA FILHO, O renascer dos povos indígenas para o Direito, Curitiba, Juruá, 1999, pages 51/52.
} 
The subject of the deep controversy that ensued between Las Casas and Sepulveda was the defense of the freedom of the peoples and recognition of nations and societies organized according to their own criteria. For Las Casas, the expropriation of native lands was a violation of the peoples' rights; to Sepulveda, the need for evangelization. According to Ruggiero ROMANO "the position of Las Casas, who wanted to free the natives from the tutelage of the 'encomenderos' is a good reflection of that of the Crown, while Sepulveda, a supporter of the "just war" against the natives and sure of the real right of the Spanish to enslave them, is merely the spokesman for the encomenderos" 6 This author goes on to say that Sepulveda received money from the Mexican encomenderos, while Las Casas was well-received by the central power. But its is evident that where such complex situations involving such a long period of time are involved, it would only be possible to isolate one or other justification for determining the behavior of the theologians mentioned.

Thus Bartolomé de Las Casas, who was a grantee on the island of Hispaniola in 1502, went to war against the natives in the search for gold, but was later to witness one of the cruelest massacres of the occupation, on the island of Fernandina, whose "strong images and such cruelty were to mark his life for ever [and] there and then he began to reflect on the iniquity of the procedures of the conquest", becoming a fervent defender of the natives 7 . Promoted to bishop of Chiapas, Las Casas contests Sepulveda, saying that the Spanish should give the natives back their dignity, freedom and the goods violently confiscated willfully, using the legal concept of the "restitutio in integrum" 8 . "Founded on the natural rights of the heathens, the Dominican believed that each nation or people had a chief and an empire ... and his legal and theological position was that all peoples were created by God and that it was up to Catholics to only take the good news of the revelation, without interfering in the life, social organization, right and property of the heathens" 9 .

For Ginés de Sepulveda, "brilliant and feral jurist" who published in Rome in 1550 "Treatise on the just cause of the war against the Indians"10, these were no more than "homunculi" (sub-human) - and it took a papal bull from Pope Paul III of 1537, Sublimis Deus, to say "sunt vero homines". Transcription of part of its text, according to Pablo RICHARD, reveals what the ideology of evangelization was concealing: "submit with weapons, if no other path is possible, those who by their natural condition must obey others and deny him the empire. ... It is just and natural that prudent, upright and human men prevail over those who are not .. With perfect right the Spanish rule these barbarians of the new world and the neighboring islands, who in prudence, genius, virtue and humanity are as inferior to the Spanish as children are to adults and women to men, there existing among them the difference between ferocious and cruel peoples and merciful people ... and almost I would say between apes and men. What more convenient or healthy thing could have happened to these barbarians than to be subjugated by the empire of those whose prudence, virtue and

\footnotetext{
${ }^{6}$ ROMANO Ruggiero, Mecanismos da Conquista Colonial, São Paulo, Perspectiva 1973, pages 48/49

7 SOUZA FILHO, O renascer dos povos..., pages 46/48

${ }^{8}$ ROULAND, Norbert, PIERRÉ-CAPS, Stephane \& POUMARÈDE, Jaques, Droit des minorités .... page 114.

${ }^{9}$ Marés de SOUZA FILHO, O renascer dos povos..., pages 46/48

${ }^{10}$ See ROMANO, Ruggiero. Mecanismos da ... page 75.
} 
religion is likely to convert barbarians - who barely deserve to be called human beings into civilized men insofar as they can be so; from sordid and libidinous, into upright and honorable; from imps and servants of the devils into Christians and worshipers of the true God?"11

These arguments especially afforded legitimacy to the right of conquest established by law ${ }^{12}$. For Sepulveda, according to Enrique DUSSEL, the foundation of the barbarism lay, among other evidence, "in its non individual manner of establishing its relations with people and things; through having no experience of private possessions or personal inheritance contract"13

This controversy was put to rest in legal terms during the XVI century by the also Dominican Brother Francisco de Vitoria, a theologian and jurist educated in Paris in the Thomism doctrine and in canon and Roman law, later a teacher in Salamanca and considered the grandfather of International Law, as he is attributed with the merit of having formulated "the law of the peoples" before Hugo Grotius, the Dutch jurist who in 1625 published De jure belle ac pacis. According to the teachings of Saint Thomas, Vitória believed in the existence of a natural law common to all men ${ }^{14}$.

In spite of agreeing with Las Casas about the injustice of Indian law of that time, Vitoria "suggests keeping Spain in America - which Las Casas repudiated, [and in this sense contradicts certain recently-mentioned affirmations by Ruggiero ROMANO] - "but with Indian law that could serve the differences between the existing peoples, creating law that is truly international or of the peoples"15

Vitória says: the land discovered when the discoverers arrived here already belonged to someone, it was not a no-man's land, and "contests the arguments that denied the Indians original domain and jurisdiction ... and establishes the question of the Indians' original sovereignty that Domingos Soto and the Portuguese jurist Francisco Soares, a professor from Coimbra, are in charge of developing"16. Vitória also went so far as to justify colonization in his doctrine, "using a sweet version of Sepulveda's prejudices ... [arguing that] the Indians had an intellectual weakness (debilitas) close to that of children. Thus one can apply the well-known concepts of the jurists: incapacity, paternal power (puissance paternelle) or tutelage, which makes it legal for the king and Spain to govern them, like a father governs his children"17. This is possibly the origin of the question of orphanhood in the king's letters and the relative capacity in our Civil Code. This question of tutelage arose in Brazil with one of the king's letters between 1686 and 1689 and was later revisited by the law of October 27, 1831.

\footnotetext{
${ }^{11}$ RICHARD, Pablo, 1492: a violência de Deus e o futuro do cristianismo, (Concilium - A voz das vítimas) Petrópolis, Vozes, 1990 pages 60/61

${ }^{12}$ ROULAND, Norbert, PIERRÉ-CAPS, Stephane \& POUMARÈDE, Jaques, Droit des minorités .... sections I and II of chapter III, pages 109 to 116

${ }^{13}$ DUSSEL, Enrique, 1492: O encobrimento do outro, Petrópolis, Vozes, 1993, page 77.

14 See ROULAND, Norbert, PIERRÉ-CAPS, Stephane \& POUMARÈDE, Jaques, Droit des minorités .... page 113

${ }_{15}$ Marés de SOUZA FILHO, O renascer dos povos..., page 51.

${ }^{16}$ This quotation was taken from CUNHA, Maria Manuela Ligeti Carneiro da, Os Direitos do índio Ensaios e documentos, São Paulo, Brasiliense, 1987, page 55.

${ }^{17}$ ROULAND, Norbert, PIERRÉ-CAPS, Stephane \& POUMARÈDE, Jaques, Droit des minorités et des peuples autochones .... page 116 .
} 
Then in 1454, Pope Nicholas' papal bull Romanus Pontifex guaranteed Portugal the right to conquer new lands from barbarians and heathens, and submit their peoples to servitude through war, while Spain secures its right to conquest under the Inter Coetera bull issued by Pope Alexander VI in 149318. And although the papal writings stuck to the official doctrine which stated that Indians were "people" and should be treated with humanity, in practice and in theory the positions and behavior were somewhat ambiguous and contradictory. What is more, many of these same writings had a foot in both camps. It is worth making a brief visit to several significant landmarks of the treatment meted out to the Indians ever since they appeared on the European scene, when men's physical and spiritual rights were defined by the Catholic Church which also quibbled about them.

Countless papal writings were published about how Indians should be treated. The Inter Coetera itself, edited by Pope Alexander VI in 1493 (following the discovery of America) "recognized the ability of Indians to accept the faith and the teachings of the Catholic Church"19 but the manner of winning over the heathens to the Catholic flock has always been something of a surprise, not only currently, but even haunting people at that time as can be seen from the controversies we can only glimpse through the cracks in these writings ${ }^{20}$.

Thus, the Inter Arcana bull issued by Pope Clement VII on May 8, 1529, when Brazil had already been discovered somewhat previously, as Mércio Pereira Gomes ${ }^{21}$ stresses, reiterates the right of the Portuguese to conquer new lands using any means - in spite of Las Casas' argument on behalf of the inhabitants of the Indies and their physical and spiritual integrity - as is made clear in the extract "let the barbarian nations get to know God, not through edicts and admonitions, but also by force and at the point of a gun, if required, so that their souls may partake of the kingdom of heaven" 22 .

On May 28, 153723, the brief Pastorale Officium of Pope Paul III once again proclaimed that the Indians were human beings and that they were capable of being evangelized, in addition to prohibiting their enslavement: "We, therefore, taking into account that these same Indians, although not residing within the bosom of the Church, are not and should not be deprived of their freedom or ownership of their chattels; and as human beings, and therefore capable of the faith and salvation, should not be destroyed by slavery, but rather invited into the (Christian) life through preaching and example"24.

According to Alípio MIRANDA \& Manuel BANDEIRA, several briefs were set down in writing whose purpose was to prevent Dom Manuel from sending missionaries to Brazil since "with the arrival of the Jesuits there began a protracted struggle between them and the

\footnotetext{
${ }_{18}$ According to Mércio Pereira GOMES. Os índios e o Brasil, Petrópolis, Vozes, 1991, page 66.

${ }^{19}$ COLAÇO, Thais Luzia, “Incapacidade Indígena. Tutela religiosa e violação do direito Guarani nas missões jesuíticas. Curitiba, Juruá, 2000. pages 87/88.

${ }^{20}$ Especially interesting are the books by DUSSEL, 1492: O encobrimento do outro and Ruggiero ROMANO, Mecanismos da Conquista Colonial, both already mentioned.

${ }^{21}$ Opus cit., to note 4 page 66 .

${ }^{22}$ Apud Mércio GOMES, page 66, citing Mecenas Dourado, in A conversão do Gentio.

${ }^{23}$ MIRANDA, Manuel Tavares da Costa \& BANDEIRA, Alípio, Memorial acerca da antiga e moderna legislação indígena, in: Carlos Frederico Marés de Souza Filho (Org) Textos clássicos sobre o direito e os povos indígenas, Curitiba, Juruá/NDI, 1992 page 30.

${ }^{24}$ Apud Thais Luzia COLAÇO, page 98 citing Paulo SUESS (Org) on page 269.
} 
Portuguese interested in the slavery of the savages, enslavement whose monetary and other results would assure them of easy riches, conveniences and pleasures" 25

The already mentioned Sublimus Deus bull (1537), considered by Thaís COLAÇO "the first social encyclical intended for the American peoples ... declared the Indians free and capable of the Christian faith, prohibiting their enslavement and reiterating their peaceful conversion through the word of God and good example".

Nevertheless, it took another script by Paul III, the Veritas Ipsa bull of June 9, 1537, placing the Indians on the same level of humanity as other men, prohibiting slavery under penalty of excommunication. In Brazil, according to Mércio GOMES, this bull only came to light a century later on April 22, 1639, with the Comissum Nobis bull of Urban VIII. ${ }^{26}$

\section{The origins of the colonization in Brazil}

Ever since Brazil was conquered/found/invaded by the Portuguese, the Indians initiated their Calvary towards genocide/ethnocide as their freedoms were physically and morally affected by the enslavement of their person and their labor, and by the plundering of their lands which literally removed the ground from under them, since their form of social organization, language and culture disappeared together with the manner in which they coexisted on their land.

When the Portuguese colonizers arrived, the aboriginal inhabitants of this land were/had been considered a people, with their own customs, traditions and language, that is, a way of life, a culture of their own which was described in prose and poetry ever since the letter of Pero Vaz Caminha, but what in fact was seen was the lighting of a candle to God and another to the devil.

For example, as J. Isidoro MARTINS Junior ${ }^{27}$ writes, partly citing Oliveira Martins in his work O Brazil e as colonias portuguezas, "since 1511 the ship Bretôa had carried from the Portuguese possession to the metropolis 'more than 30 Indian' captives; that the letters and charters of the port administration entitled the captain to "rescue an indeterminate number of slaves, sending thirty-nine to Lisbon each year, and using them as he saw fit without paying any taxes; ... and as many others as needed for the sailors and cabin boys on his ships". This at the same time shows the omnipresent ambiguity surrounding the consideration regarding the humanity and the treatment to which the natives of Brazil were entitled by mentioning "that the main reason for having Brazil populated was to reduce to the Catholic faith those who did not believe, seeing to it that they were well treated, and in the event they were hurt or molested, reparation was to be made to them and those responsible punished".

According to Marés, although many laws were decreed regarding the Indians of Brazil, Portugal built nothing resembling the "Leyes de Indias". The Decrees of the Kingdom applied in full and were adapted quite often by interpreting non-explicit mutations, as was the case of the land tenure (sesmarias) ${ }^{28}$.

\footnotetext{
${ }^{25}$ MIRANDA, Manuel Tavares da Costa \& BANDEIRA, Alípio, Memorial acerca da ...., opus cit, page 30. ${ }^{26}$ Mércio GOMES, pages 57 and 109. this is also the opinion of ALMEIDA, Naíde Azevedo de, Indio II, Enciclopédia Saraiva de Direito, 43, São Paulo, Ed. Saraiva, 1977, page 463. ${ }^{27}$ J. Isidoro MARTINS Junior, História do Direito Nacional (Co. 1895), Pernambuco, Cooperativa Editora e de Cultura Intelectual, 1941, 2nd ed., page 203.

${ }^{28}$ Carlos Frederico Marés de SOUZA F ${ }^{\circ}$., O renascer dos povos ... page 53.
} 
On the one hand, there were the colonists interested in enslaving the Indians and taking possession of their lands; and on the other, the representatives of the Catholic Church, and their intention of converting the heathens to the Catholic faith and of obtaining temporal power in the form of lands; and furthermore, given the unknown immensity of the land conquered, there is the fact that the metropolis served these two masters and therefore, maintaining lax control, pursuing a contradictory policy - see the King's letter of 1537 which expressly enshrined the enslavement of the Caetés - seconded as it was by D. Sebastian on March 20, 1570, which stated that it was impossible to render the Indians captive unless "they were taken in a just war and those that usually set upon the Portuguese and other Indians, but, says TOURINHO NETO29 "when taken in a just war authorized by the king or governors, or in morning rushes in which they attack and rob the houses, assassinating the inhabitants, or when they kill their enemies and eat them". The truth is that the use of weapons for indoctrination and land tenure was continually a reason for declaring and pursuing "just wars".

The 1548 Regiment, which succeeded the King's Letter of 1537 dates from this time, "of dubious intention and contradictory to the hilt. That is why, ordering the governors to treat the Indians in general well, at the same time it commanded them to wage war against those who were the enemy, destroying their villages and settlements, capturing and killing them, and executing in their own villages, for example, any chiefs they could imprison" $"$.

This behavior of the authorities in Brazil and the discussion at hand also suggest the disintegration that was appearing in the medieval world, and which would culminate in the Renaissance and the Reformation which exploded in the XVII century.

\section{From the XVII century to the republic}

The XVII century, now under Philip II, begins with a positive reaction to freedom, as is made clear in the provision of July 5, 1605 and the law of June 30, 1609 which entitled the Indians to private law and a curator of their interests. But this legal protection was shortlived, since as they advanced inland - the official incursions (Bandeiras), the explorers and the expeditions to imprison and capture Indians for slave labor - there was lobbying in Portugal by both the Church and the colonists for and against Indian slave labor, all with the intention of settling and taking possession of their lands. Papal bulls, king's letters, writs and regulations were published, some asking for leniency and humane treatment, like the king's letters of 1605, 1609, 1647, 1648 and 1680, immediately followed by others like those of $1611,1667,1673$ and 1684 which encouraged mistreatment and enslavement. ${ }^{31}$

Enlightenment and the valuing of so-called natural man, which deemed to find man through reason, made possible the transition from metaphysical natural law to rationalist natural law, and enabled jus naturalism to consider individual rights as not representing a

\footnotetext{
${ }^{29}$ TOURINHO NETO, Fernando da Costa, Os direitos originários dos indios sobre as terras que ocupam e suas conseqüências jurídicas. In Juliana Santilli (coord.) Os direitos indígenas e a constituição, Porto Alegre, Sérgio Fabris, 1993, page 12, citing Joquim Norberto de Souza Silva in an article published in the RIGH of 1854 .

${ }^{30}$ MIRANDA, Manuel Tavares da Costa \& BANDEIRA, Alípio, Memorial acerca da antiga e moderna legislação indígena. In Carlos Frederico Marés de Souza Filho, Textos clássicos sobre o direito e os povos indígenas. Curitiba, Juruá/NDI, 1992 page 31

${ }^{31}$ Manuel MIRANDA \& Alípio Bandeira, opus cit, pages 31 et sec.
} 
creation of the state, but that the latter had to ensure that these were observed and preserved. Especially to the fore were the right to life, liberty, security and property 32 , while one of the approaches of this new attitude was the famous bull issued by Benedict XIV on September 20, 1741, already in the XVIII century, confirming the briefs of Paul III and Urban VIII "once again, excommunicating latae setentiae, the violators of Indian liberty. And including them all in the same irrevocable condemnation, it hurled threats not only at those who henceforth were to be guilty of selling, buying, exchanging Indians or giving them as presents, set apart from their families, dispossessed of their chattels and farms, taken to other lands, transportation or other deprivation of liberty, but even those who gave advice, favor and help to whoever did such things, whatever the pretext for doing them." 33

The relations between religious missionaries and the Crown agents were always tense, with disagreement on how to "civilize" the Indians. D. José I enacted the Pombal Directory created by the Writ of May 3, 1755, referring only to Pará and Maranhão, later extended to Mato Grosso where it only made itself felt in $1761^{34}$ when it substitutes the action of religious missionaries with laymen in Indian villages; grants liberties to the Indians and orders lands to be demarcated for them. ${ }^{35}$ But the king's letter of May 121798 abolishes the Pombal Directory "and promotes the Indians to the condition of orphans, while returning to the concept of defensive wars and allowing white men to settle freely on Indian lands". ${ }^{36}$

In the XVIII, therefore, we see the continuation of casuistry and contradictions, servitude of the Indians and the despoiling and occupation of the lands where they lived, quite often with the support of the law while the authorities turned a blind eye when the interests of the colonists, the Crown and the Church were concerned, contrary to the interests and rights of the indigenous peoples. And what is more, as J.F. Lisboa observes, "Portuguese legislation was an uninterrupted series of hesitations and contradictions until Pombal. Today, unrestricted capture was decreed; tomorrow, absolute freedom, then a halfway house between the two extremes. Decrees were made and revoked, compromises made" 37.

In spite of the Declaration of Virginia in 1776, the Rights of Man and the Citizen, 1789, the French Revolution of 1798, the United Kingdom of Portugal, Brazil and Algarves which began with the arrival of D. João VI, the first three king's letters were published in 1808 and another in 1809, turning back the clock on cruelty and extermination and evidencing the strength of local power in the face of the king's proximity. These laws were relatively relaxed by the king's letter of 1811 and by the writ of May 1812 to the Governor of the Relation of the city of São Luiz do Maranhão, which did not consent to mistreating the heathens, or coercing them into forced labor for arbitrary prices and time periods. ${ }^{38}$

\footnotetext{
32 Se LEWANDOWSKI, Enrique Ricardo, Proteção dos Direitos Humanos na Ordem Interna e Internacional, Rio de Janeiro, Forense, 1984 pages 8 to 12.

${ }^{33}$ Apud Alípio MIRANDA \& Manuel BANDEIRA, opus cit., page 35.

${ }^{34}$ LEVERGER, Augusto (Barão de Melgaço), Apontamentos cronológicos da Província do Mato Grosso. Rev do Instituto Histórico e Geográfico Brasileiro, 205: 1949, pages 252/253.

${ }^{35}$ See page 73 of the book Os índios e o Brasil, by Mércio GOMES, Rio de Janeiro, Vózes, 1988.

${ }^{36}$ Mércio GOMES, idem.

${ }^{37}$ Citation in Manuel MIRANDA \& Alípio Bandeira, Memorial acerca da antiga e moderna ... page 30.

38 OLIVEIRA SOBRINHO, Os silvicolas brasileiros e a legislação pátria - O decreto legislativo No. 5.484 of 1928. In Carlos Frederico Marés de Souza Filho, Textos clássicos sobre o direito e os povos indígenas. 93-124. Curitiba, Juruá/NDI, 1992, page 104.
} 
While this was going on, in Imperial Brazil of 1823, especially on the private initiative of the congressmen Carvalho e Mello, Souza França and José Bonifácio, the Indian question on several occasions became the center of attention of the Constituent General Assembly of the Empire. The Indian policy inspired in José Bonifácio and his Annotations offered to the respective committee, concerned "the problem of two suffering races - the African and the American", whose wise concepts regarding the Indians were only taken up again and disclosed in full 87 years later with the creation of the Indian Protection Service (SPI) in 191039, since D Pedro I dissolved the constituent assembly and José Bonifácio was deported as a suspicious element where public order was concerned.

However, also according to OLIVEIRA SOBRINHO, the ideas of creating a new nation appear. The Empire's Indian policy based on “Decree No. 426 of July 1845, officially baptized as Regulations concerning the missions for indoctrinating and civilizing the Indians ... the law of public service organization in regard to the Indians" 40 creates the village settlement regime, establishes the general directives for the Indians in the provinces, which in turn created partial directives for villages and groups of villages, favors indoctrination, prohibits servitude and mistreatment of Indians, obligates them to public service with a salary and to military service, but without coercion and correctional imprisonment of up to 6 days. ${ }^{41}$

The government of the first regency, on behalf of the Emperor, "issued the famous law of October 27, 1831 [which revoked the king's letters of 1808] ... of a protective nature, releases the Indians from all servitude, orders them to be considered orphans, subjecting them to the Ordinance regime, book I, title $88 . .$. Also in the sense of considering them as orphans, the decree of June 3, 1833 was issued under which by virtue of the extinction of the chamber ombudsmen who were private judges and administrators of Indian chattels, the judges of orphans became responsible ... The regulations of 1842 once again stipulate that it is incumbent on the judges of orphans to administer the Indian chattels" 4243.

In the second half of the XIX century, inspired by the evolutionism of Auguste Comte, we see the beginning of the Positivist Apostolate of Brazil movement whose proposal was to have the Indians considered as peoples of free and sovereign nations and whose voice made itself heard at the time of the Republican Constituent Assembly "on behalf of the poor heathens

\footnotetext{
${ }^{39}$ OLIVEIRA SOBRINHO, opus cit, pages $107 / 108$.

${ }^{40}$ According to Carlos Frederico Marés de SOUZA F., Tutela aos índios: Proteção ou Opressão? In Juliana Santilli (Coord) Os direitos indígenas e a constituição. Porto Alegre, Sérgio Fabris/NDI. 1993, 296-312, on page 300 .

${ }^{41}$ Mércio GOMES, opus cit., pages 79/80.

42 According to MIRANDA \& BANDEIRA, opus cit., pages 41 to 45.

${ }^{43}$ Carlos Frederico Marés de SOUZA F ${ }^{\circ}$ begins his already cited chapter Tutela aos indios: Proteção ou Opressão? by telling a sad case judged by the Supreme Court of Maranhão on October 25, 1898, which denied the plea of habeas corpus of the Indian Helena to have her son who has been placed in the care of strangers returned to her, alleging that the orphan courts enjoy special attributions in regard to Indians and their possessions and, as a result, if the mother is unable to manage her own life, how could she even manage that of her son, as she is a real savage with no knowledge at all of the Portuguese language. This decision, according to the author, was published in vol 79 of the monthly journal of Legislation, Doctrine and Jurisprudence, The Law, referring to May-August 1899 on pages 780-2. This interpretation, that in addition to the chattels the courts were competent to rule on the persons of the Indians, which included relieving them of their paternal power, involves an error, as Marés comments. I ask was this not the interpretation that was to leave traces in the Brazilian Civil Code of 1916 ?
} 
... proposing recognition of the "Brazilian American States" [in opposition to the other states of the Federation, the Brazilian Western States] which would be supported by federal Government protection and fully respected in possession of their territories .... And when the legislators voted article 63, subsequently 64 of the Constitution, it did not transpire that they left to luck the real owners of the Brazilian land, handing over to the States, together with the unoccupied lands, those lands that were occupied in the most legitimate of manners" 44 .

The Constitution of 1891 did not concern itself with the Indians scattered across the national territory, and article 64 already mentioned declares as belonging to the state the mines and unoccupied lands, and to the Union only the portion of the territory indispensable for border defense, fortifications, military constructions and federal railways, not including the Indian colonies or settlements. Nor did it reserve the right of the Indians to possession of vast and diverse tracts of land which they legitimately occupied, committing a regrettable injustice and a huge political error by once again leaving them subject to local polices, without proper protection, since plunder and pillage were and have been a constant behavior of the state and the Brazilian people.

For José Afonso da SILVA, the lands are the Indians' original entitlement - the indigenato, an old and traditional Luso-Brazilian legal institution whose roots go back to the time of the colonies. Citing João MENDES JR, he says "The indigenato is the primary and congenital source of land tenure: it is a hereditary right, while the occupation is a vested right". João Mendes Jr. goes on to add "as the lands are congenitally possessed, they are not unoccupied, that is, they are originally reserved... These considerations on their own show that the relations between the Indian and his lands are not governed by the rules of Civil Law"45.

He goes on to say "the relations between the Indian and his lands ... his possession extrapolates the purely private sphere and is the basis for his habitat in the ecological sense of joint interaction between natural and cultural elements that afford the balanced development of human life.. This type of relation has nothing to do with the individualist limitations of private law" 46 .

This article 64 of the Constitution of 1891, which associates without differentiating unoccupied lands from Indian lands, including the latter in the former, is the result of countless still unresolved actions, or those resolved to the detriment of the Indians, in transit in our courts. Here I would cite the summary published by Aurélio Wander BASTOS47:

\footnotetext{
${ }^{44}$ MIRANDA, Manuel Tavares da Costa \& BANDEIRA, Alípio, Memorial acerca da antiga e moderna legislação indígena. In Carlos Frederico Marés de Souza Filho, Textos clássicos sobre o direito e os povos indígenas. Curitiba, Juruá/NDI, 1992 page 50.

${ }^{45}$ SILVA, José Afonso da, Terras tradicionalmente ocupadas pelos índios In Juliana Santilli (coord.) Os direitos indígenas e a constituição. Porto Alegre, Sérgio Fabris/NDI. 1993, 296-312, page 48. Several researchers have also spoken out on this point, like Aurélio Wander Bastos, C.F. Marés de Souza Fo, Fernando da Costa Tourinho Neto.

${ }^{46}$ Bruna FRANCHETTO, O que é "Terra Indígena"? Uma decisão do Supremo Tribunal Federal, In: Silvio Coelho dos Santos et allii (orgs.) Sociedades Indígenas e o Direito - uma questão de direitos humanos Ensaios. Florianópolis. UFSC/CNPq. 1985. page 107 cites José Afonso da SILVA in a lecture given at the USP Law School, October 1983.

${ }^{47}$ Aurélio Wander BASTOS. As terras indígenas no Direito Constitucional brasileiro e na jurisprudência. In: Silvio Coelho dos Santos et allii (orgs.) Sociedades Indígenas e o Direito - uma questão de direitos humanos - Ensaios. Florianópolis. UFSC/CNPq. 1985. page 88
} 
“The Writ of Mandamus No. 20.234 (MT) of the Federal Appeals Court (STF) dated June 4, 1980 (RTJ journal No. 99, p.70) explicitly states in a decision regarding the constitutionality of Decree No. 84.337, of 21/DEC/79 that establishes the boundaries of the Parabubure Indian Reservation: the right to dominion and possession of the State of Mato Grosso (the first grantee of the lands) has been conferred upon it by the Constitution of the Republic of 1891, and no document can be demanded of it as proof of its dominion". This guideline has been a dominant feature within the STF starting with the decision handed down in Extraordinary Appeal No. 51.290 (GO) of 24/SEP/1968 (RTJ magazine No. 48, p. 49) regarding dominion of public assets, which in that sense recognizes the validity of the acts of transfer of the unoccupied lands by the states of the federation".

Article 4 of the Federal Constitution of 1946, according to Ney LAND, speaks of lands occupied by savages, "without care all their lands were the property of the union, which has been creating more difficulties when it should have made indispensable reservations regarding:

1. the lands donated to the Indians for them to establish their villages;

2. the lands donated by one Indian to another - usually a tribal chieftain - for him to establish his village;

3. the lands donated to Indians in payment of services rendered;

4. the lands acquired by the protecting entity (FUNAI) for establishing Indian villages.

As one can see, these four types of Indian lands should not only be demarcated, but rather they should have a normal deed of title properly registered with the Registrar of Deeds" 48 .

\section{The $X X$ century}

The ideals of the Positivist Apostolate were not very successful and the means of communication at that time reverberated with complaints of mistreatment, which worsened in the south when the German colonies began hiring professional Indian hunters (bugreiros) "to exterminate Indians who were preventing the progress of civilization", so as to be able to occupy their lands. The echoes of these actions were heard in Europe, and at the Congress of Americanists held in Vienna in 1907, severe accusations were leveled at Brazil for "allowing enslavement and even encouraging the extermination of the Indians" 49 . Thus, under external pressure, on June 20, 2010 the government of Nilo Peçanha approved Decree No. 8072 which created the Indian Protection Service (SPI) and Domestic Workers Localization.

The soul of this decree were the supporters and members of the Apostolate led by the future Marshal Cândido Mariano da Silva Rondon, who had already traveled throughout Brazil putting up telegraph poles, and whose motto "die if needs be, but never kill" was not mere

\footnotetext{
${ }^{48}$ According to Ney LAND, an Indian specialist with 20 years of services to the Indian cause. In: O Índio e o Direito. PAINEL. Rio de Janeiro. OAB/RJ (Brazilian Bar Association/Rio de Janeiro Chapter).

OAB/RJ Debate Series. 1981. pages 87/88

${ }^{49}$ According to what several specialists in the Indian question have written and described, among them, Darcy RIBEIRO, Os índios e a civilização - A integração das populações indígenas no Brasil moderno -

São Paulo, Cia das Letras, 1996; Carmen JUNQUEIRA \& Eunice PAIVA, La legislación brasileña y las poblaciones indígenas en Brasil. In: Rodolfo Stavenhagen, Derecho indígena y derechos humanos en América Latina Mexico, Instituto Interamericano de Derechos Humanos/El Colégio de México, 1988; Mércio Pereira GOMES, Os índios e o Brasil. Rio de Janeiro. Vozes. 1988; Roberto Cardoso de OLIVEIRA, Roque de Barros LARAIA, and many other anthropologists, jurists, indigenists and persons with extensive knowledge of the dry Brazilian uplands (sertão).
} 
rhetoric as witnessed by his countless followers, intellectuals, liberal professionals, armed forces personnel and many who had worked with him in building the telegraph lines, in addition to historical and scientific documents. Of special interest is the book by Darcy Ribeiro: Os índios e a civilização. Unfortunately the pacification of over 100 tribes facilitated their future extermination through the failure of the Brazilian state to act, on the one hand, and on the other hand, that state's permissiveness and complicity in plundering the lands, even after ratifying the international laws for the protection of minorities, like the Convention 107 of the ILO of June 1957 on the protection of Indian populations, ratified in 66 ; and that of the UN, of December 65, ratified in 69, regarding the elimination of all kinds of racial discrimination.

The initial project of the Civil Code, according to CLOVIS BEVILÁCQUA, did not highlight the Indians among those considered incapable, nor did it even mention them, just like TEIXEIRA DE FREITAS in Esboço, as it was believed that they deserved special arrangements like any other autonomous people and which best served their condition as individuals "strangers in the nest of Civilization that the Civil Code represents, although organized society insists in sitting them on its lap". Incapacity took place in the Senate on the proposal of Muniz Freire, labeling them as individuals of restricted capacity. According to CLOVIS, to whom the savages are inhabitants of the forest and not those who were mixed in with the general population, the matter of special arrangements began to be resolved with Decree No. 8.072 of June 20, $1910^{50}$.

The SPI was created under the Ministry of Agriculture, subsequently linked to the War Ministry, before returning to Agriculture. Under the Statute of the Indian, mediation between the natives and state was to have been the responsibility of the FUNAI, created in December 1967 and linked to the Ministry of the interior. However, "the FUNAI is run by the military, when this task should belong to the Judiciary, with better access" says Nilo Batista51 and citing a friend "a colonel running the FUNAI is as logical as the battle of Monte Castelo being won by an anthropologist".

In 1961, president Jânio Quadros created new forest parks or reserves in areas with dense concentrations of Indians, including the Sete Quedas National Park on the border with Paraguay and the Xingu Indian Park Reserve (PIX) in the region that begins with the tributaries of the $\mathrm{Xingu}^{52}$, to which the ferocious participation of those who defended the Indians and their way of life made an enormous contribution, in this case the Villasboas brothers. But Bruna FRANCHETTO53 writes, "In 1953, while Congress was analyzing the bill of law that sought to create the Xingu Indian Park Reserve with a larger area than that of today, the Lands Department of the State of Mato Grosso began selling lands throughout the state in order to pursue a 'colonization policy' ... which included two-thirds of the Park Reserve area". On August

\footnotetext{
${ }^{50}$ Clovis BEVILÁCQUA, Código Civil dos Estados Unidos do Brasil - Comentado, Rio de Janeiro, Franciso Alves Bookstore, 1921, vol. 1, 2nd ed. page 185.

51 Nilo BATISTA, professor and Director of the Research Division of the OAB/RJ Chapter. In: O índio e o Direito. PAINEL. Rio de Janeiro. OAB/RJ. OAB/RJ Debate Series. 1981, page 97

52 MOREIRA Neto, Carlos Alberto. Constante histórica do indigenato no Brasil. Antropologia 2: 175-185. São Paulo/USP, 1967, page 178

${ }^{3}$ Bruna FRANCHETTO, O que é "Terra Indígena"? Uma decisão do Supremo Tribunal Federal, In: Silvio Coelho dos Santos et allii (orgs.) Sociedades Indígenas e o Direito - uma questão de direitos humanos Ensaios. Florianópolis. UFSC/CNPq. 1985. See note (1) pg. 116 and page 99.
} 
10, 1983, after the BR-080 highway had cut the PIX from end to end, the STF handed down a decision condemning the Union and the FUNAI to pay for the indirect expropriation of an area of land of around 10.000 hectares which had been sold by the State of Mato Gross in 1959.

Paulo SABOYA54, when asked why Indian lands cannot be demarcated, which should have happened according to the Statute of the Indians (1973) within five years following its enactment, says that the shock begins because it is communal, not condominium ownership, resulting in a basic difficulty, namely "society is unable to swallow the pill of communal ownership within the capitalist system".

The coup of 64 removed the SPI management from office, finally extinguishing the entity, but not before a fire took place in its confidential files that were never published, which by then had been transferred to Brasilia. The FUNAI "linked the meaning of work to the ideology of development with security" based on contacting new autonomous groups, demarcation of lands, providing formal education and health, and all this very quickly. Not all targets were fully attained, fortunately, according to Mércio GOMES55.

The Constitution of 67 and the Additional Act of 69 made the Indian lands non negotiable and their possession permanent, with the exclusive right to enjoy their natural wealth. The Indian land, the matter of relative incapacity and the definition of who is or is not an Indian has been the fulcrum of many injustices and transgressions against the dignity and rights of the Indians, and the Gordian knot of the biggest portion of the Indian question since its origins ${ }^{56}$.

The Statute of the Indians created by law 6.001 of December 19, 1973 was the FUNAI's work tool, but did not provide guardianship as it should have, partly because of the lack of political will, or by the pressure of economic power, taking land away from the Indians for hydroelectric plants, railways and highways, abusing the powers of guardianship as illustrated in several works, as it was its own inspectorate; or through lack of personnel, in part trained personnel; or because of corrupt employees, among other causes. From an individual viewpoint, the case of Juruna is especially exemplary ${ }^{57}$.

\footnotetext{
${ }^{54}$ Paulo SABOYA, Director of the OAB/RJ Chapter. In O índio e o Direito. PAINEL. Rio de Janeiro. $\mathrm{OAB} / \mathrm{RJ}$, page 25.

${ }_{55}$ Mércio GOMES, opus cit., pages 88/90.

${ }^{56}$ There are countless works dealing with these three topics. Here we have only mentioned a few, but in the publications found in the bibliography, the reader will find the points of view of jurists, anthropologists, indigenists and former and current specialists in matters of the dry Brazilian uplands dealing with this matter in some depth.

57 "In 1980, the chief of the Namunkurá Xavante village was Mario Juruna, who had become the most important representative of the Indian struggle in Brazil, and elected president of the Commission of the $4^{\text {th }}$ Bertrand Russell Human Rights Tribunal", "having been invited to travel abroad to present the situation of the Brazilian indigenous populations to human rights protection agencies. Taking advantage of the guardianship imposed by the Statute of the Indians, the Interior Minister, hierarchical boss of the President of the FUNAI, forbid him to leave the country" (see SOUZA FILHO, 1993, and the chapter of Carmen JUNQUEIRA \& Eunice PAIVA mentioned below, respectively). According to what Rafael José de Menezes BASTOS, who saw the case notes of this proceeding tell us "Having taken the dispute to the courts, the Mário Juruna affair basically involves the writs of habeas corpus filed with the Federal Appeals Court under No. 4.876, (dated November 13, 1980) and 4.880 (of the 17th) on behalf of the Xavante Chief's freedom to come and go, so that he could appear at
} 
The military government, and even those that succeeded them, paint scant attention to the demarcation of lands, and from the developmentalist perspective allowed many projects to be installed on Indian lands - which, among other problems, transmitted diseases and spread epidemics among the Indians - highways (like the Transamazônica and CuiabáSantarém in the 1970s); and railways (the Carajás-Itaqui railway); dams and hydroelectric power stations, inundating their habitats (for example, the traditional lands of the Parakaná at Tucuruí); the installation of companies: farming and livestock companies like those of the "Polonordeste" Program, not to mention lands invaded by colonists and farmers, as was the case of the Pataxó Indians in Ilhéus whose legal struggle to have their lands returned to them continues to this day; mining for gold and precious stones (see the cases of the Surucucus and Yanomani Indians); exploitation of timber (among others, Mato Grosso, on Cinta-Larga lands) and minerals like bauxite and cassiterite, predominantly in the States of Pará and Minas Gerais (as is the case of Paranapanema and Vale do Rio Doce on lands belonging to the Kaiapó, Guajá and Waimiri-Atroari Indians). Many of these projects are based on matters of national security, but whose exploration was granted not only to stateowned companies, but also to private Brazilian and multinational companies ${ }^{58}$.

Civil movements and societies that appeared through the involvement of Indians from different tribal societies, anthropologists, jurists and other defenders of the cause were able to muster their forces to have the current articles 231 and 232 and their paragraphs included in the 1988 Federal Constitution. This was an enormous step forward towards the belated enfranchisement of the indigenous peoples. The new constitutional rulings enable the structuring of a large number of indigenous associations registered as civil societies, which in the Amazon region rose from 10 to 80 in a single decade, covering only the 6 states of the Amazon (Amazônia (AM), Rondônia (RO), Roraima (RR), Acre (AC), Pará (PA) and Amapá $(\mathrm{AP})$ ), and which currently, since the advent of the XXI century, are estimated at over 250 if we consider only the territory covered by the Legal Amazon area which has been fighting for its rights, although aware from experience ever since the time of its ancestors, that more injustices and prejudices exist and are yet to appear.

Nevertheless, the fact that favorable legislation exists for the primeval inhabitants of this land has been insufficient to change the mindset and the attitudes of part of the Brazilian population. Laws have a positive effect on possible behaviors, as expressed in this increase

the Bertrand Russell Tribunal. It is notable that the FUNAI and the Ministry of the Interior publicly - through newspapers, magazines, etc - refused to grant approval for $\mathrm{Mr}$. Juruna to appear at the event, which was evidenced in practical terms by the refusal of the Federal Police to issue him with a passport. The writs having been filed, the first by Mr. Jorge de Oliveira Beja, and the second by José Oliveira Costa and Antonio Modesto da Silveira, both of them were dedicated to only one manner, the reporting party being Minister Adhemar Raymundo". This author concludes: "the case having been won by Mr. Juruna, precisely on account of the inspiration that the ministers of the Federal Appeals Court sought in the Universal Declaration of Human Rights and in the Constitution" even so, "the habeas corpus received 15 votes in favor and nine against, whereby he was able to leave for Holland where he accompanied the final part of the work of the $4^{\text {th }}$ Tribunal", according to Carmen JUNQUEIRA \& Eunice PAIVA, opus cit., page 267.

58 I suggest reading the chapter of Carmen JUNQUEIRA \& Eunice PAIVA La legislación brasileña y las poblaciones indígenas en Brasil. In: Rodolfo Stavenhagen, Derecho indígena y derechos humanos en América Latina Mexico, Instituto Interamericano de Derechos Humanos/El Colégio de México, 1988; and the chapters of Mércio GOMES, on pages 165 to 186 for a better understanding of the difficulties and atrocities imposed on the Indian tribes. 
in civil societies among the indigenous peoples. But on the other hand, there is the example of the new Civil Code, law 10.406 of 2002, which once again puts the Indians under the main paragraph of the relatively incapable, a guideline which is barely suitable for the approach of the latest Magna Carta.

This historical social inheritance, a sad memory of over 500 years of mistreatment suffered by countless groups of Brazilian indigenous peoples retains its presence in different strata of Brazilian society, while certain economic and political interests speak louder, which for the different aboriginal peoples of our nation means an endless struggle.

\section{References}

Almeida, Naíde Azevedo de, Índio II, Enciclopédia Saraiva de Direito, 43, São Paulo, Ed. Saraiva, 1977.

Bastos, Aurélio Wander, As terras indígenas no Direito Constitucional brasileiro e na jurisprudência. In: Silvio Coelho dos Santos et allii (orgs.) Sociedades Indígenas e o Direito - uma questão de direitos humanos - Ensaios. Florianópolis. UFSC/CNPq. 1985.

Bastos, Rafael José de Menezes, Sobre a noção de tutela dos povos e indivíduos indígenas pela União. In: Silvio Coelho dos Santos et allii (org.) O Índio perante o Direito: ensaios. Florianópolis, Ed. UFSC, 1982.

Batista, Nilo, In: O índio e o Direito. PAINEL. Rio de Janeiro. OAB/RJ. OAB/RJ Debate Series. 1981.

Bevilácqua, Clovis Código Civil dos Estados Unidos do Brasil - Comentado, Rio de Janeiro, Franciso Alves Bookstore, 1921, vol. 1, 2nd ed.

Colaço, Thais Luzia, "Incapacidade Indígena. Tutela religiosa e violação do direito Guarani nas missões jesuíticas. Curitiba, Juruá, 2000.

Cunha, Maria Manuela Ligeti Carneiro da, Os Direitos do índio Ensaios e documentos, São Paulo, Brasiliense, 1987.

Dussel, Enrique, 1492: O encobrimento do outro, Petrópolis, Vozes, 1993.

Franchetto, Bruna, O que é "Terra Indígena"? Uma decisão do Supremo Tribunal Federal, In: Silvio Coelho dos Santos et allii (orgs.) Sociedades Indígenas e o Direito - uma questão de direitos humanos - Ensaios. Florianópolis. UFSC/CNPq. 1985.

Gomes, Mércio Pereira, Os Índios e o Brasil, Rio de Janeiro, Vozes, 1988.

Junqueira Carmen \& Paiva Eunice, La legislación brasileña y las poblaciones indígenas en Brasil. In: Rodolfo Stavenhagen, Derecho indígena y derechos humanos en América Latina Mexico, Instituto Interamericano de Derechos Humanos/El Colégio de México, 1988.

Land, Ney, In: O Índio e o Direito. PAINEL. Rio de Janeiro. OAB/RJ (Brazilian Bar Association/Rio de Janeiro Chapter). OAB/RJ Debate Series. 1981. pages 87/88.

Lewandowski, Enrique Ricardo, Proteção dos Direitos Humanos na Ordem Interna e Internacional, Rio de Janeiro, Forense, 1984.

Leverger, Augusto (Barão de Melgaço), Apontamentos cronológicos da Província do Mato Grosso. Rev do Instituto Histórico e Geográfico Brasileiro, 205: 1949.

Martins Junior, J. Isidoro, História do Direito Nacional (Co. 1895), Pernambuco, Cooperativa Editora e de Cultura Intelectual, 1941, 2nd ed. 
Miranda, Manuel Tavares da Costa \& Bandeira, Alípio, Memorial acerca da antiga e moderna legislação indígena. In Carlos Frederico marés de Souza Filho, Textos clássicos sobre o direito e os povos indígenas. Curitiba, Juruá/NDI, 1992.

Moreira Neto, Carlos Alberto. Constante histórica do indigenato no Brasil. Antropologia 2: 175185. São Paulo/USP, 1967.

Oliveira Sobrinho, Os silvicolas brasileiros e a legislação pátria - O decreto legislativo No. 5.484 of 1928. In Carlos Frederico Marés de Souza Filho, Textos clássicos sobre o direito e os povos indígenas. 93-124. Curitiba, Juruá/NDI, 1992.

Richard, Pablo, 1492: a violência de Deus e o futuro do cristianismo, (Concilium - A voz das vítimas) Petrópolis, Vozes, 1990.

Romano Ruggiero, Mecanismos da Conquista Colonial, São Paulo, Perspectiva 1973.

Rouland, Norbert, Pierre-Caps, Stephane \& Poumarède, Jaques. Droits des minorités et des peiples autochtones. Paris, Presses Universitaires de France, 1996.

Saboya, Paulo, In O índio e o Direito. PAINEL. Rio de Janeiro. OAB/RJ, 1981.

Silva, José Afonso da, Terras tradicionalmente ocupadas pelos índios In Juliana Santilli (coord.) Os direitos indígenas e a constituição. Porto Alegre, Sérgio Fabris/NDI. 1993.

Souza Filho, Carlos Frederico Marés de. (Org) Textos clássicos sobre o direito e os povos indígenas, Curitiba, Juruá/NDI, 1992.

Tutela aos indios: Proteção ou Opressão? 296-312 In Juliana Santilli (coord.) Os direitos indígenas e a constituição. Porto Alegre, Sérgio Fabris/NDI. 1993.

O renascer dos povos indígenas para o Direito, Curitiba, Juruá, 1999.

Tourinho Neto, Fernando da Costa, Os direitos originários dos índios sobre as terras que ocupam e suas conseqüências jurídicas. In Juliana Santilli (coord.) Os direitos indígenas e a constituição, Porto Alegre, Sérgio Fabris, 1993. 


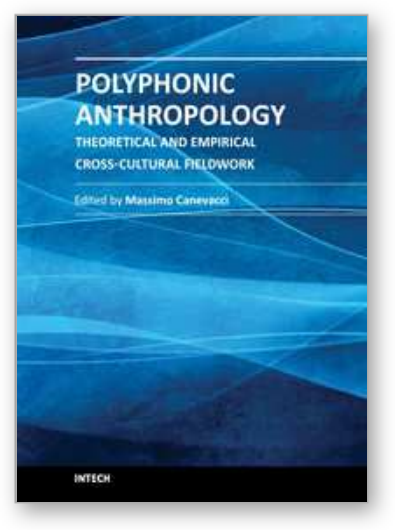

\author{
Polyphonic Anthropology - Theoretical and Empirical Cross- \\ Cultural Fieldwork \\ Edited by Prof. Massimo Canevacci
}

ISBN 978-953-51-0418-6

Hard cover, 242 pages

Publisher InTech

Published online 23, March, 2012

Published in print edition March, 2012

This book connects anthropology and polyphony: a composition that multiplies the researcher's glance, the style of representation, the narrative presence of subjectivities. Polyphonic anthropology is presenting a complex of bio-physical and psycho-cultural case studies. Digital culture and communication has been transforming traditional way of life, styles of writing, forms of knowledge, the way of working and connecting. Ubiquities, identities, syncretisms are key-words if a researcher wish to interpret and transform a cultural contexts. It is urgent favoring trans-disciplinarity for students, scholars, researchers, professors; any reader of this polyphonic book has to cross philosophy, anatomy, psychology, psychoanalysis, sociology, architecture, archeology, biology. I believe in an anthropological mutation inside any discipline. And I hope this book may face such a challenge.

\title{
How to reference
}

In order to correctly reference this scholarly work, feel free to copy and paste the following:

Maria Stella Ferreira Levy (2012). The Matter of the Sovereignty of the Heathen Peoples, Polyphonic Anthropology - Theoretical and Empirical Cross-Cultural Fieldwork, Prof. Massimo Canevacci (Ed.), ISBN: 978953-51-0418-6, InTech, Available from: http://www.intechopen.com/books/polyphonic-anthropologytheoretical-and-empirical-cross-cultural-fieldwork/the-matter-of-the-sovereignty-of-the-heathen-peoples

\section{INTECH}

open science | open minds

\author{
InTech Europe \\ University Campus STeP Ri \\ Slavka Krautzeka 83/A \\ 51000 Rijeka, Croatia \\ Phone: +385 (51) 770447 \\ Fax: +385 (51) 686166 \\ www.intechopen.com
}

\author{
InTech China \\ Unit 405, Office Block, Hotel Equatorial Shanghai \\ No.65, Yan An Road (West), Shanghai, 200040, China \\ 中国上海市延安西路65号上海国际贵都大饭店办公楼 405 单元 \\ Phone: +86-21-62489820 \\ Fax: +86-21-62489821
}


(C) 2012 The Author(s). Licensee IntechOpen. This is an open access article distributed under the terms of the Creative Commons Attribution 3.0 License, which permits unrestricted use, distribution, and reproduction in any medium, provided the original work is properly cited. 